\title{
LRMSC Grade 4, Skin
}

National Cancer Institute

\section{Source}

National Cancer Institute. LRMSC Grade 4, Skin. NCI Thesaurus. Code C121173.

Ulceration. 